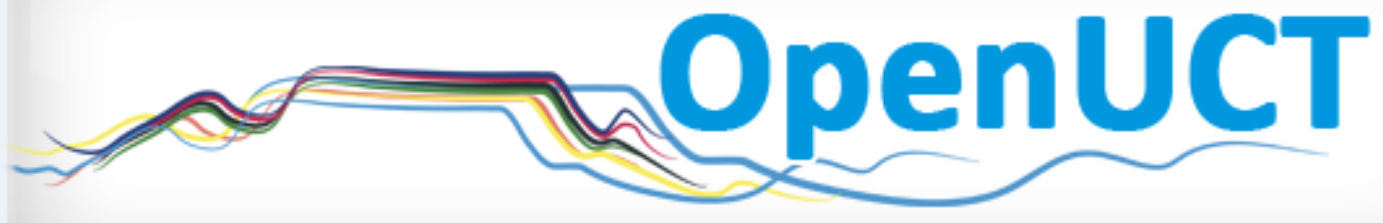

This is the author-approved manuscript version of a journal article published in:

Bangeni, B. 2009. Negotiating between past and present discourse values in a postgraduate law course: implications for writing. Southern African Linguistics and Applied Language Studies. 27(1): 65-76. DOI:10.2989/SALALS.2009.27.1.6.754.

It is made available under the terms of agreement between the author and the journal, and in accordance with the University of Cape Town's Open Access Policy for the purposes of research, teaching and private study.

http://www.openuct.uct.ac.za/sites/default/files/UCTOpenAccessPolicy.pdf 


\title{
Negotiating between past and present discourse values in a postgraduate law course: implications for writing
}

\author{
Bongi Bangeni \\ Centre for Higher Education Department, University of Cape Town. \\ E-mail: Abongwe.Bangeni@uct.ac.za
}

\begin{abstract}
This article reports on some of the findings from a year-long qualitative case study which explores the transition experiences of seven ESL students from the Humanities into postgraduate studies located in the Law and Commerce faculties at a historically white university. Here I focus on two of the students who were registered for honours in Criminology and explore the ways in which undergraduate discourse values manifest in their writing. Focusing on one course, Criminal Law, and within that the legal problem question answer (PQA) genre, I draw on Toulmin's (1958) model of argumentation to investigate how the students established links between warrants and claims in adapting to the genre conventions and modes of argument construction within their new discipline. The data reflect that, in addition to struggles around form, the challenges encountered by the students can be attributed broadly to a tension between their embodied habitus and the epistemological characteristics of the new discipline. One manifestation of this is in their challenges with negotiating the communicative purposes of the PQA where they explore available spaces for Social Science oriented reasoning in a genre shaped by 'objective' tests and legal principles. The findings underscore the importance of actively engaging students on how their prior literacies impact on the process of negotiating the intellectual and cultural demands of specialised genres at postgraduate level.
\end{abstract}

\section{Introduction and background}

In 2001, the Department of Education declared its objective of increasing graduate outputs within South African higher education (DoE, 2001). This was largely in response to growing concerns over the low percentages of postgraduate degrees awarded in South Africa's institutions of higher learning as well as the high drop-out rates at postgraduate level as reflected in the Department's National Plan for Higher Education in South Africa. In the light of these concerns, institutions of higher learning have identified the recruitment and retention of postgraduate students as a strategic area. A key concern fuelling this decision is, amongst other things, the fact that students are graduating from their undergraduate studies in large numbers, but these numbers are not maintained at postgraduate level (see DoE, 2001).

Considerable research has been conducted into student writers' transition into postgraduate studies. The research has focused mainly on their entry into postgraduate research programmes (Wisker et al., 2003) and on support networks for international postgraduate students (Angelova \& Riazantseva, 1999; Guilfoyle, 2006). Attention has seldom been extended to the transition experiences of postgraduate students entering into coursework programmes (see also Symons, 2002, who makes the same observation), more specifically where one of the disciplines has a different epistemological grounding to those within which their undergraduate degree majors were located. This gap is particularly evident within the discipline of academic law.

Research conducted within the law discipline has tended to center around first year students' entry into the LLB programme (Diaz et al., 2001; Weber, 2001; Baderin, 2005; Ngwenya, 2006). With the exception of Ngwenya (2006), this research emanates from outside of South Africa. In the South African context the transition from social science oriented disciplines into academic law as well as the implications of this transition for the context-specific writing practices with which the student writer is expected to engage remains to a large extent unexplored. 


\section{Conceptual framework}

Situated writing and discourse communities

The shift from generalist views of writing to context-specific ones foregrounds the situated nature of writing (see for example, Barton \& Hamilton, 2000). Besides characterising writing as a social practice, this shift brings into sharp focus the social constructivist-based notion of a discourse community as espoused by New Literacy Studies theorists such as Gee (1990). This term has been broadly used to refer to 'a group of people who share certain language-using practices' (Bizzell, 1992: 222). Pertinent to this definition is the process by which new members of the community come to know what is seen to be worth communicating, how to communicate it and what knowledge they need to draw on in persuading other members to believe what they are communicating (see Faigley, 1985). Theorists have increasingly conceptualised academic disciplines as discourse communities (for example Bizzell, 1982; Swales, 1990). This conceptualisation points to the fact that, like discourse communities, disciplines have characteristic ways of expressing things. Of concern to this article are the ways in which arguments are 'generated, developed and expressed' (Becher, 1989: 23) in distinct disciplines and the content from which the student writer can legitimately draw in the process of constructing an argument. I consider this in relation to what the students bring with them from their undergraduate disciplines and the implications of this for the student's induction into the new discourse community.

The process of induction into discourse communities is not without conflict. In theorising about this process, authorities such as Harris (1989) and Gee (1990) point to a tension that is brought about by a conflict between past and present discourses. This tension is evident in the findings of several studies on student writers' induction into various disciplinary discourse communities (see for example, Sutton, 1997; Ivanič, 1998; Herrington \& Curtis, 2000; Bangeni \& Kapp, 2006). Sutton (1997: 48), for instance, cites examples of research studies which illustrate the challenges encountered by student writers who 'import procedures which had worked well for them in the past' into other learning contexts where these procedures do not prove to be as effective. Within this area of research, the ways in which the student writer attempts to reconcile the discourse conventions and values of past and current disciplines are highlighted.1

\section{Discourse communities and the assimilation of a worldview}

Arising out of the above notion of a discourse community is the question around the extent to which a discourse community can be said to be constitutive of one's worldview. Whereas Swales (1990) argues that it is possible to deploy the conventions and engage with the values of a discourse in a detached manner, guided mainly by instrumental motives, Bizzell (1992: 228) argues that 'if we acknowledge that participating in a discourse community entails some assimilation of its worldview, then it becomes difficult to maintain the position that discourse conventions can be employed in a detached, instrumental way'. In reviewing these positions I tend to lean more towards Bizzell's argument. However, I would argue that the extent to which a discourse community is able to impress its worldview on its members is dependent on a number of factors. The data on which I base my conclusions signal that the degree to which one is invested in the discipline, as well as the length of time spent in the discipline, is significant in evaluating the extent to which student writers come to assimilate the worldview impressed upon them by the various discourse communities within which they are members. Time and investment would then be the conditions under which Bizzell's notion becomes valid to me. To clarify what I mean by 'worldview', I draw on Bourdieu's notion of habitus.

\section{Bourdieu's notion of habitus}

Bourdieu's (1990) theory of social practice attempts to offer an explanation of human action in the face of structural determinacy. In doing so, it traces an individual's practices and actions within societal structures to dominant socialising agents in one's life which would include education. At the centre of this process is habitus. Bourdieu defines the concept in the following terms: "cumulative exposure to certain social conditions instills in individuals an ensemble of durable and transposable dispositions ... collectively referred to as habitus which structures new experiences in accordance 
with those existing structures produced by an individual's past experiences' (Bourdieu \& Wacquant, 1992: 13). Embedded within this definition is the notion that the habitus, acquired through prolonged participation in a discourse community, then comes to shape the worldview of individuals and ultimately their actions in that and other discourse communities. Relating the notion of habitus to my research context offers a lens through which to view the ways in which the students attempt to reconcile the discourse conventions and values of their new discourse community with those which they acquired as a result of membership in dominant ones at undergraduate level. More specifically, it sheds light on how individuals come to position themselves and are in turn positioned in specific ways as a result of the worldview they bring with them. This then affects how they view the conventions and values of the new discourse community. While studies on context-specific writing have contributed to an understanding of the ways in which student writers adapt to new writing contexts (see Berkenkotter et al., 1988; Berkenkotter \& Huckin, 1995; Bangeni \& Kapp, 2006), studies that seek to explore this transition and its implications for one's worldview and writing practices within the discipline of academic law remain minimal.

\section{Research context and questions}

In an attempt to address the above-mentioned gap in research, this article, which draws on a broader study focusing on the transition experiences of seven postgraduate students into the Law and Commerce faculties at a historically white university, explores two of these students' attempts to negotiate the discourse conventions and values of Criminal Law. Both students had identified this course as being the most challenging one for which to write. The course is located within the Law faculty's Department of Criminal Justice and focuses on the general principles of criminal liability.

As part of their undergraduate studies, the students, Harold and Andrew (pseudonyms), were registered for Bachelor of Social Science degrees in the Humanities faculty from 2002 to 2004. They, along with 18 other first year Humanities students, had participated in a three year longitudinal study conducted by myself and colleague, Rochelle Kapp, during that period (see Bangeni \& Kapp, 2007, for a detailed description of this study and our methodology). Having witnessed their negotiation of the undergraduate discourses within their disciplines and how these had come to shape their worldview, especially in their last undergraduate year, I became interested in how, upon graduating and proceeding to postgraduate study, they would reconcile these with the worldviews informing their new disciplines.

Upon graduating in 2004 with majors in Psychology and Sociology and after not qualifying for honours in Psychology, they took the decision to register for honours in Criminology. This is an interdisciplinary programme for students who graduate from the Humanities faculty. The degree is jointly offered by the Graduate School of Humanities (GSH) and the Law faculty's Department of Criminal Justice. In 2005 it was comprised of four courses: Interdisciplinary Research Methods (offered by the GSH), with Crime and Criminology, Criminal Procedure and Criminal Law all administered by the Law faculty. 2 In a reflection paper they wrote just before they graduated, the students described how their passion for Psychology had led to an interest in Criminology. In an interview conducted in the first semester where he explained their decision to register for the degree, Andrew stated: '... so getting a degree in Criminology is going to allow [us] to go back into the original discipline [we] wanted to do. Despite the law courses - the core law courses - the programme is interesting because I can do my research focus, that's the nicest thing about it. I'm able to do that and stuff, but it's also very demanding' (Interview 1, 2005). Significantly, Andrew had made a similar strategic move in his first undergraduate year where he registered for Social Work in order to access Psychology after not having met its competitive entrance requirements.

Apart from reflecting the role that their attachment to Psychology had played in their choice of postgraduate degree, Andrew's statement pointed to how the struggles that he encountered in his transition were specifically related to the law courses he had to do as part of this degree, specifically Criminal Law. I then became interested in the ways in which the distinct knowledge-making practices and discourse conventions in Criminal Law intersected with those of Psychology and Sociology, and how this intersection manifested in the students' postgraduate writing. In order to explore this, I asked the broad question: 'in what ways are undergraduate discourse conventions 
and values evident in postgraduate writing?', which I attempted to answer by asking the following specific questions:

1. In transitioning to a new discipline, how do postgraduate students view the discourse conventions and values they come with from undergraduate study?

2. How do they view the discourse conventions and values in their new disciplines?

3. How are some of these views evident in their writing?

Focusing on the genre of the legal Problem Question Answer (PQA) in Criminal Law, I argue that, in addition to struggles around form, the challenges encountered by the students can be broadly attributed to a tension between their embodied habitus (Bourdieu, 1990), which is shaped by their undergraduate disciplines, and the culture of the new discipline. One particular manifestation of this is in their challenges with negotiating the communicative purposes of the PQA where they explore available spaces for social science-oriented reasoning in a genre shaped by 'objective' tests and legal principles.

\section{The PQA genre}

This genre, a dominant one in Criminal Law, trains students to produce 'the kind of legal rhetoric needed to apply legal reasoning to the facts of a case, an essential skill for a lawyer' (Bruce, 2002: 324). This genre consists of five reasoning moves collectively referred to as FILAC (Facts, Issue, Legal principles, Application of law to facts, and Conclusion). The student is presented with the established facts which s/he uses to determine the legal issues to be considered. More often than not there are a number of issues to consider and the student has to present and discuss them, followed by a discussion of the law (legal principles, statutes) to be applied to the issues at hand. In the last reasoning move the student applies the legal principles in question to the established facts, which is where s/he determines the likely outcome of the case.

\section{Methodology}

In acknowledging writing as a socially situated act, I used qualitative methods to arrive at an understanding of students' engagement with new disciplinary discourses. I used the interviews as a space for the students to reflect on their transition to postgraduate studies and the implications of this for their writing practices in their respective disciplines. Intending to rely, to a certain extent, on the students' perceptions of this change, I conducted two face-to-face semi-structured interviews with each student in the first and second semesters of 2005, in April and August respectively. This process entailed a comparison of the discourse conventions and values of their new disciplines with those of their undergraduate ones. In the first interview I aimed to gain a general sense of how the students were experiencing the transition and the implications that this transition had for them as individuals, while the second interview focused specifically on their writing practices.

In order to gauge how the students' perceptions of their writing practices manifested in their writing I asked them to submit marked essays from their courses throughout the first and second semesters of their first postgraduate year. They also each wrote a reflection paper detailing their experiences of writing for new disciplines, where they reflected on the epistemological differences between Psychology, Sociology and Criminal Law. After doing a preliminary analysis of their writing, I saw the need to interview a Criminal Law lecturer who could shed light on the workings of the PQA genre and the overall values of the discipline. In the process of analysing the data mentioned above and in comparing the discourse conventions of the undergraduate and postgraduate courses in question, I drew on the corpus of data yielded by the three year longitudinal study mentioned earlier in the article, which I used to triangulate the textual analysis (Stake, 1994). Having access to multiple sources of data served to validate my interpretations of the students' overall transition experiences while simultaneously addressing the perceived lack of rigor in case study research (Yin, 2004).

\section{Analysis of interview transcripts}

Contrasting past and present discourse conventions and values

In the second interview which took place later in the year in August when the students would have

had sufficient exposure to the discourse conventions and values of Criminal Law, I engaged the 
students in a discussion about their experiences of writing for a new discourse community. I based the discussion on two marked essays that I had asked them to select for discussion in the interview.

In the following statements, which address the question, 'in transitioning to a new discipline, how do postgraduate students view the discourse conventions and values they come with from undergraduate study?', the students were commenting on the discourse conventions and values of the PQA:

- 'the discourse is very reductionistic in my opinion as I was unable to bring in my background' (Andrew)

- 'having to apply the facts to the various tests and concepts is one of the most difficult things I have to do' (Harold)

- 'the solving part for me is not so easy, the applying law to facts part' (Harold)

- 'the application of law to facts is difficult - that particular part I always get wrong' (Andrew)

In the same interview the students spoke of the struggles they encountered in their engagement with the genre, struggles which they attributed to the differences between the discourse values of undergraduate and postgraduate discourse communities:

- "coming from the Humanities sphere, I was used to having to take into account the various factors that play a role on the behavior and the manner in which a person goes about in the world and now having to overlook this is very hard on me' (Harold)

- 'unlike in my undergraduate ... there is not much room for looking into the broader social, economical and political factors and there is not much room to manoeuvre' (Harold)

- 'I am fortunate coming from a discipline (Psychology) where I was able to integrate various perspectives in my writing' (Andrew)

- 'the discipline (Criminal Law) is too fixed in their knowledge' (Andrew)

What the first group of statements point to is a struggle with structuring arguments; a struggle highlighted by Beasley's study whose findings indicated that one of the challenges encountered by students in engaging with legal writing lies primarily in 'organizing answers to legal problem questions' (Beasley, 1993: 7). The second group of statements reflects struggles around the factors they could legitimately draw on in constructing arguments. Consequently, my analysis of their texts focused on two aspects: (i) exploring the ways in which they developed logical reasoning within and between the different sections of the PQA; and (ii) the factors they drew on in substantiating their arguments. This analysis then worked toward addressing the third research question which sought to explore the ways in which the students' views manifested in their PQAs. Since the students' challenges with the PQA are linked to the nature of the argument they are expected to produce for the genre (Andrew likened the argument construction to solving a mathematical equation), I drew on Stephen Toulmin's model of argumentation to establish how the students established links between the different reasoning moves in eight PQA texts - four from each student - which they had written for Criminal Law.

\section{Analysis of the writing}

Toulmin's model of argumentation

Toulmin's (1958) model, which is based on jurisprudence, puts forth six characteristics to forming an argument, namely: grounds or data; warrant; backing; qualifier; claim, and rebuttal. At its most basic his model illustrates how established data (D) move through a warrant $(\mathrm{W})$ which then becomes the assumption on which the claim $(C)$ is based. More often than not the warrant requires additional backing $(\mathrm{B})$. The backing adds to the validity of the warrant and thus to the validity of the claim. Consider the following example:

- Established facts: a professional swimmer sees a child drowning and does not rescue the child because he does not feel obligated to do so.

- Let us imagine that the warrant in this particular instance is as follows: an act considered contra bonas mores (contrary to public policy, which refers to what the public deems as morally binding and to which one is held accountable) will result in punitive action being taken against the perpetrator. In backing this warrant the student then draws on a case that made use of the legal principle of contra bonas mores. 
-Based on this warrant and the subsequent backing presented, the claim would therefore be that the accused is guilty as his actions are contrary to public policy. Within FILAC the warrant would be stated under the 'legal issues' reasoning move while the claim/or judgment would be provided at the end as part of the 'application of law to facts' reasoning move.

This reasoning move requires that the student draw on the warrant/s presented earlier to assist him or her in making the claim at the end. This differs from the nature of argument construction which is endorsed in the Social Sciences, where the claim tends to appear upfront in the introduction. In my analysis I focus on warrants and claims specifically as the students' statements in the interviews reflected that their struggles with the PQA genre were located mainly in the last reasoning move which carries the claim, where they are required to analyse the established facts in terms of what is dictated by the laws, acts and statutes which constitute the warrants on which their arguments are based.

Even though Toulmin's model has been criticised for a number of reasons, one being that it fails to consider challenges to the claim (see for example, Van Eemeren et al., 1987; Leitão, 2001), it presented me with useful categories within which to classify the different reasoning moves of the PQA. It also enabled me to establish how reasoning developed from one category to the next and to note instances where it broke down. To this end the marker's comments, which reflected the expectations and conventions of the discipline, guided my critical analysis of the texts and subsequent interpretations of the students' challenges with the genre, challenges which I discuss below.

\section{Challenges with the PQA}

In analysing the students' writing it seems that they were able to identify correctly those instances in the PQA which presented challenges. Indeed, their problems with the genre did appear to be concentrated in the last reasoning move, in the application of law to facts. However, what my analysis illustrates is that challenges with the genre were directly linked to the two cognitive moves the students were required to make, firstly in selecting and applying key legal principles from cases to the problem in question and also in providing relevant backing for their warrants.

\section{Selecting and applying key legal principles}

The challenge with selection of relevant information is evident in Andrew's interview where he makes reference to the difficulty of knowing exactly what to select in a case. He states, '... analysing those (cases), is so difficult to write. You need to set up a principle ... you need to know what to extract from these cases ...' This inability to select the relevant information from cases is evident in their writing. For example, in two of his PQA samples, Andrew applies principles relevant to specific cases (or to types of cases) to the cases under consideration. In one of them, under the 'legal issues' reasoning move, he draws on the principle actio liberia in causa which can only be used in consequence crimes. He applies it to the case under consideration which is classified as a circumstance crime.

Similarly, Harold gives a detailed explanation of causation and dolus eventualis (DE - where the accused foresees the possibility of the prohibited crime occurring) in his 'legal issues' reasoning move of a different PQA, but does not use these two principles in his application of law to facts reasoning move where he makes his claim on the basis of negligence, which he does not include in his review of the relevant legal issues to be considered. The tutor comments: 'only discuss the relevant principles and cases - why do you dwell so much on causation \& DE when you don't really use these in your application?' In making his claim it becomes evident that he is not sure as to why he has included the above legal principles as part of his argument as he eventually bases his claim on a different legal principle. Drawing on an example from the judicial system, Toulmin (1958: 93) observes that 'it is often necessary in the law courts, not just to appeal to a given statute or common law doctrine, but to discuss explicitly the extent to which this particular law fits the case under consideration'. Likewise, Swales (1982: 140) in foregrounding the difficulties posed by attempting to decipher/interpret legal cases, observes that this process involves determining 'whether a fact is material, or whether a particular case is distinguishable from another one' [his emphasis]. 


\section{Challenges with backing}

Challenges with backing manifested in two ways: either the warrant was absent at the beginning of the PQA or it was provided but not backed with the relevant legislation.

Absent warrants

In one of his earlier PQAs, written at the beginning of the year, Andrew sets out the established facts (data) as presented in the problem question. However, there is no discussion of the previous cases that were used as precedence to determine the fate of the accused. At the end of the PQA he makes the claim that 'Dlamini (the accused) not guilty, acquitted on the basis that he was acting involuntary and had no motive or intention'. Upon going back to the beginning of the PQA to see whether he had provided the relevant warrant that would have allowed him to come to this conclusion, it became evident that the warrant had not been provided. This then compromised the validity of his claim.

\section{Providing relevant cases and acts in backing warrants}

Similarly, in discussing emotional stress and provocation in one PQA Harold does not cite authority for the argument that he is putting forward, which is linked to the warrant he has provided. In discussing the relevant legal principles he begins his paragraph thus:

Legal duty to act:

In South African law the general rule in this regard is expressed in the leading delict case of Minister van Polisie v Ewels that a person is under no legal duty to protect another from harm, even though he or she can easily and ought morally to do so. However there are exceptions:

- A legal duty to act may arise where some prior conduct on the part of the person has created a potentially dangerous situation

- Where a person has control of a potentially dangerous thing or animal.

In considering the various rebuttals to this warrant, he does not back these with the relevant cases or acts. So, even though the tutor comments 'good' alongside the above extract, she brackets the bulleted points and writes, 'authority?' next to them. In advancing the argument that he makes with regards to the centrality of context in argument construction Toulmin (1958: 96) maintains that 'the sort of backing called for by warrants varies from one field of argument to another ... the kind of backing we must point to if we are to establish its authority (warrant) will change greatly as we move from one field to another'. In the field of Criminal Law backing requires that the student writer provide relevant cases and/or statutes and acts on which the warrant is based and in this context these are the sources that have the most authority.

What the data show is that the challenge is not a simplistic one that just has to do with structuring argument. My analysis points to the fact that the students' struggles with argument construction were not solely evident within the last reasoning move, the 'application of law to facts', as they concluded in the interviews and reflection papers. As is illustrated by the above categories, struggles with this last reasoning move were a manifestation of difficulties with earlier moves within the PQA. These difficulties included the inability to identify and apply the relevant principles to the cases under consideration, struggles with providing relevant backing for warrants, as well as omission of crucial information. These then had a direct bearing on the validity of the claim in the last reasoning move. What the students seem to be overlooking here is the interconnectedness of the different sections of the PQA, where the first section is 'a kind of roadmap to the second section' (Interview with Criminal Law lecturer, February 2007). The claim put forth in the last reasoning move can differ from one answer to the next; what is important is how well the writer is able to substantiate it by showing how the content in that section relates to that of the sections before it.

Having illustrated through my analysis that the majority of the struggles reflected by the PQA samples were linked to backing, I proceed to show how this particular challenge also translated into the factors that students felt they should be able to include (and in some cases, did) as backing for the claims they made.

\section{'But we see other things': drawing on socio-economic factors}

In the interviews both Harold and Andrew spoke of how the PQA genre limited the extent to which 
they, in assessing the criminal liability of the accused, could consider factors other than the cases and laws used to set precedence. Harold expresses their mutual frustration in the following way: '... the law doesn't allow you to look at things in a more broader sense, if you are given a case, this is what it is. You can see the implications, the effects other aspects of society have on the case but they don't require you to do that ... you can't bring in broader stuff ... you focus on the principle. It restricts one from looking at other alternatives.'

When I probed and asked what he meant by 'broader stuff' he responded:

'... you see the case that is presented and you feel but we see other things. The case is presented in such a way that you can see all these sociological, economical kinds of problems but you can't mention them. "It has nothing to do with that", the Law says and that's what it is ... but then for someone like myself with a background in Psychology, I would look and see clearly that integrity plays a role or belief plays a role and we can't overlook that because it is circumstantial ...' (Interview 2, 2005).

In attempting to illustrate specific moments in their writing where the above tension is evident, I selected one of the PQAs that Harold wrote in the first semester. In starting out he correctly identifies the relevant principles set out by the Criminal Procedures Act. However, in trying to back up his claim that the accused acted reasonably in shooting the deceased he bases his conclusion on South Africa's social problems, where he foregrounds the high levels of crime instead of the legal principles he has identified in the first part of the PQA:

'South Africa has one of the largest car theft incidences in the world and has become quite a serious offence and [in] the country. Many of the suspects are never arrested and many of them are very dangerous and linked to car high-jacking (sic) which is possibility in this incidence in that the deceased could possibly have simply high jacked another vehicle and possibly kill another member of the public ...'

In the interview Harold explains why he approached his answer in the way he did. He refers to a consultation where he was discussing an earlier draft of this PQA with his tutor:

'... just the idea of going about it (the argument) because of the way we do things, the way we approached things [in Sociology] in terms of first looking at the society, but she's like "okay" but that's not what she wants, she wants the principles and cases ... this means you don't enter into a kind of debate about what possible things could have led to the action.'

This quotation illustrates his frustration with what both he and Andrew perceive as the lack of 'room to manoeuvre'. Here, Harold juxtaposes one of the ways of approaching knowledge in the discipline of Sociology, where debate is central in the production of knowledge, with that of Criminal Law, where contestation happens via 'a body of rules' (Becher, 1989: 8). This traditionalist nature of the discipline is reflected in the following observation by Twining (1997: 39) who notes that 'the conservative values of consistency and certainty (in the sense of settled doctrine) repeatedly nudge out other values'.

\section{Discussion}

Exploring the space for broader socio-economic factors

The problem that Harold experiences in engaging with the genre is evident in the following quote from Tredoux et al. (2002: 25) who argues: 'the two sides [Psychology and Law] articulate and defend different boundary positions ... While both share a claimed interest in understanding and predicting human behaviour, they differ in terms of grounds for legitimate authority ... Here is a potential source for boundary clashes'.

The values and conventions which make up his habitus make it difficult for Harold to negotiate the expectations of his new discipline. His struggles with the PQA genre culminated in him failing Criminal Law in the June examination, an examination where problem questions dominate. Having said this, it is important to point out that I am not by any means attributing his failure solely to the above reason. The previous section clearly illustrates how his failure could have been due to the structural difficulties around the genre as much as a clash in worldviews. Yet, when one considers the disciplines of Psychology and Sociology and their approaches to explaining human behaviour, Harold's action of attributing his struggles to the epistemological orientations of his undergraduate 
majors becomes a legitimate one. In arguing that disciplines are inherently different, Becher (1989: 5) makes reference not only to the 'social norms that mark off the members of one academic culture from another', but also to 'the epistemological characteristics of the types of enterprise on which the academics in question are engaged' (see also MacDonald, 1994). He makes reference to the discipline of Sociology where 'the core ... lies in exploring the action of social forces and understanding the principles of change in society'. This involves 'looking for generalities, seeking causal explanations ... with knowledge that has explanatory power ...' (Becher, 1989: 8). Academic law, by contrast, places authority on an established body of legal doctrine on which it bases its reasoning. The challenge for Harold, it seems, lies in his inability to strike a balance between drawing on South Africa's prevalent social problems in constructing his argument and giving space to the laws and principles that form the foundation of his new discipline.

In an interview with the Criminal Law lecturer, we discussed the extent to which the student writer is able to legitimately draw on those factors which both students deem to be central to their argument. She maintained that substantiations falling outside of the immediate legal principles were acceptable as long as they were preceded by 'an acknowledgement of the current law as it stands' (Interview with Criminal Law lecturer, 2007). As a member of this discourse community Harold has to know how much space he can afford to the social factors he draws on, which in his and Andrew's opinions represent a more credible source of authority surpassing that of legal rules and objective tests.

\section{The role of time and investment in the assimilation of a worldview}

While Harold spoke of his attempts to challenge the discipline, Andrew described how he felt he was losing his voice in the process of conforming to the discourse conventions and values of Criminal Law. In the second postgraduate interview, where he describes his academic career as a journey, he stated: 'I am learning to leave those things outside now, sure I bring them up in the discussions we have in the tutorials but that's far as that goes'. His critique of the Law discipline where he states, 'I could never be a lawyer, I cannot afford to look at things the way they do!' (Interview 2, 2005), is significant when looked at alongside a statement he made in the reflection paper he wrote in his third year. In showing how he had acquired the social norms of Psychology, which he claimed were apparent in how he approached knowledge and in how he reasoned, he reflected: 'I have gone from being in the discipline to where I am the discipline' (see Kapp \& Bangeni, 2006). These statements reflect not only the significance of the length of time spent in a discourse community and the implications of this for assimilation of its worldview, but also the significance of the extent to which one is invested in the discipline.

Having explored the challenges these students encountered in writing for the Law discipline and their aversion to its discourse values, the fact that they were not as invested in the discipline as they were towards Psychology does go some way towards offering a plausible explanation for their strong reactions to it. In his undergraduate reflection paper for example, Harold wrote about how his performance in Psychology was tied to his investment in the discipline, 'I score better in my Psychology essays ... due to the fact that I see myself becoming a clinical psychologist in the end and would therefore put more work and emphasis in that field'. Although they did acknowledge that they were slowly coming to a realisation of the importance of adapting to the culture of Criminal Law, this acknowledgment appeared to be driven largely by the desire 'to graduate and leave the Law faculty' (Andrew, Interview 2, 2005) rather than coming to terms with the worldview informing the discipline.

Bourdieu (1990) characterises the modus operandi of the habitus as shaping not only individuals' actions but also how they respond to the practices and values inherent in the fields in which they participate. Even though Bourdieu sees the habitus as functioning largely at an unconscious level, Giddens (1979: 57) draws attention to the conscious intentions of the individual; "the capabilities of human agents to 2 "explain" why they act as they do by giving reasons for their conduct'. The two students are thus able to reflect on the practices and identities that are perceived as being guided by their habitus. It is the practices and values within psychology and sociology to which they attribute their negative stance towards the discourse of Criminal Law. This new context requires new ways of thinking and believing $(G e e, 1999)$ which ultimately influenced not only their 
writing practices but also the perceived effects of the new discourse community on their values and attitudes. The following statement with which Andrew ends his last interview is telling: 'on the one hand you realise that you are learning new things but you also feel like you've kind of lost something along the journey' (Interview 2, 2005).

\section{Conclusion}

In this article I have illustrated how, in encountering a new genre at postgraduate level, the students who are the focus of this article attempt to negotiate not only its form but the worldview they have to 'take on' in producing the genre. Harriet Malinowitz writes about the often disempowering effect of the writing-in-the-disciplines movement and how it forces student writers to adhere to the dominant disciplinary conventions and values which influential and prominent members seek to preserve at all costs. In seeking some kind of remedy to this problem, she argues that 'students should know that they have strategic choices - to play by the established rules or to challenge them - and should be helped to find appropriate support for each choice' (Malinowitz, 1998: 309). While I agree with what she posits, based on my data I would argue that the implications for challenging dominant discourses are likely to vary according to the nature of the discipline and are therefore likely to have more serious implications in some discourse communities. In a discipline like Law - and in a course like Criminal Law with its rigidly structured PQA genre - whose discourse conventions and genre boundaries appear more clearly defined than those of other genres in other disciplines, challenging its discourse conventions and values, as Andrew quickly learns, is best done in tutorial discussions than in the formal writing. In the light of this, what Harris (1989) concludes could go some way in addressing this tension. He maintains that, in initiating students into the values and practices of a new community, academics need to make available to students 'the chance to reflect critically on those discourses ... to which they already belong' (Harris, 1989: 19). This needs to be an important part of the process of inducting postgraduate students into new disciplines; one that needs to occur alongside a thorough demystifying of the intellectual and cultural demands of the specialised genres therein.

\footnotetext{
Notes

'I use the term discourse conventions in the fashion of Johns (1997: 31) - who draws on Swales' (1990) model of moves - to refer to the 'global organization of the text' with a specific focus on the 'moves' that make up the different sections of the PQA rather than its sentence-level elements. Discourse values points to the ideologies and epistemological characteristics inherent in a particular discipline which would also include what constitutes credible sources of authority therein.

${ }^{2}$ Since 2007 the honours in Criminology curriculum has been restructured by amalgamating the law modules Criminal Law and Criminal Procedure to form one course - Criminal Justice Process.
}

\section{Acknowledgments}

I would like to express my gratitude to Anne Herrington for her guidance in analysing the data on which this article is based, as well as for her feedback on the drafts that followed. Thanks are also extended to the following people for their various contributions: Ermien van Pletzen; members of the Postgraduate Literacies Project in CHED; Langelihle Nkabinde; the two students who are the focus of this article; and the two anonymous reviewers for their helpful comments on the article. Finally, I would like to thank Rochelle Kapp, who gave a great deal of her time in providing feedback on drafts.

\section{References}

Angelova M \& Riazantseva A. 1999. 'If you don't tell me, how can I know?' A case study of four international students learning to write the U.S. way. Written Communication 16(4): 491-525.

Baderin MA. 2005. Towards improving students' attendance and quality of undergraduate tutorials: a case study on law. Teaching in Higher Education 10(1): 99-116.

Bangeni B \& Kapp R. 2006. 'I want to write about the Dalai Lama ...' Literacies in transition. In Thesen $L$ \& van Pletzen E (eds) Academic Literacy and the languages of change. London: Continuum Publishers, pp 67-83. 
Bangeni B \& Kapp R. 2007. Shifting language attitudes in a linguistically diverse learning environment in South Africa. Journal of Multilingual and Multicultural Development 28(4): 253-269.

Barton D \& Hamilton M. 2000. Literacy practices. In Barton D et al. (eds) Situated literacies: reading and writing in context. London: Routledge, pp 7-15.

Beasley CJ. 1993. Language and content: the case of law. In Bird N, Harris J \& Ingham M (eds) Language and content. Hong Kong: Institute of Language in Education, pp 304- 330.

Becher T. 1989. Academic tribes and territories: intellectual enquiry and the cultures of disciplines. USA: Open University Press.

Berkenkotter C \& Huckin TN. 1995. Genre knowledge in disciplinary communication: cognition/ culture/ power. Hillsdale, NJ: Erlbaum.

Berkenkotter C, Huckin TN, Ackerman J. 1988. Conventions, conversation, and the writer: case study of a student in a rhetoric Ph.D. Program. Research in the Teaching of English 22(1): 9-41.

Bizzell P. 1982. College composition: initiation into the academic discourse community. Curriculum Inquiry 12(2): 191-207.

Bizzell P. 1992. Academic discourse and critical consciousness. Pittsburgh: University of Pittsburgh Press.

Bourdieu P. 1990. The logic of practice. Stanford, California: Stanford University Press.

Bourdieu P \& Wacquant L. 1992. An invitation to reflexive sociology. Chicago: The University of Chicago Press.

Bruce N. 2002. Dovetailing language and content: teaching balanced argument in legal problem answer writing. English for Specific Purposes 21(4): 321-345.

Department of Education. 2001. National Plan for Higher Education in South Africa. Pretoria: Department of Education.

Diaz RJ, Glass CR, Arnkoff DB \& Tanofsky-Kraff M. 2001. Cognition, anxiety, and prediction of

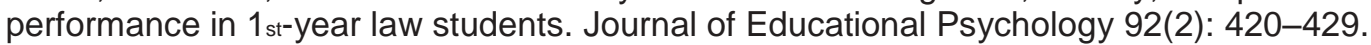

Faigley L. 1985. Nonacademic writing: the social perspective. In Odell L \& Goswami D (eds) Writing in nonacademic settings. New York: The Guilford Press, pp 231-248.

Gee J. 1990. Social linguistics and literacies. Ideologies in discourses. London: Falmer Press.

Gee J. 1999. An introduction to discourse analysis: theory and method. London: Routledge.

Giddens A. 1979. Central problems in social theory: action, structure and contradiction in social analysis. London: Macmillan Press.

Guilfoyle A. 2006. Peers, family, community, supervisors and governance: a review of key sites for supporting international postgraduate students' transitional learning experiences. Experience of learning. Proceedings of the 15th Annual Teaching Learning Forum, 1-2 February 2006. Perth: The University of Western Australia [Available at: http://lsn.curtin.edu.au/tlf/tlf2006/refereed/ guilfoyle.html].

Harris J. 1989. The idea of community in the study of writing. College Composition and Communication 40(1): 11-37.

Heath SB. 1983. Ways with words: language, life, and work in communities and classrooms. Cambridge, England: Cambridge University Press.

Herrington A \& Curtis M. 2000. Persons in process: four stories of writing and personal development in college. Urbana, Illinois: National Council of Teachers of English.

Ivanič R. 1998. Writing and identity: the discoursal construction of identity in academic writing. Philadelphia: John Benjamins Publishing Co.

Johns AM. 1997. Text, role, and context: developing academic literacies. United Kingdom: Cambridge University Press.

Kapp R \& Bangeni B. 2006. Positioning (in) the discipline: undergraduate students' negotiation of disciplinary discourses. Paper presented at the African Studies Association Conference, San Francisco, November 2006.

Leitão S. 2001. Analyzing changes in view during argumentation: a quest for method. Forum: Qualitative Social Research 2(3) [Available at: http://www.qualitative-research.net/fqs-texte/301/3-01leitao-e.htm]. 
MacDonald S. 1994. Professional academic writing in the Humanities and Social sciences. Edwardsville: Southern Illinois University Press.

Malinowitz H. 1998. A feminist critique of writing in the disciplines. In Jarratt S \& Worsham L (eds) Feminisms and composition studies: in other words. New York: MLA, pp 291-312.

Ngwenya T. 2006. Integrating language awareness with critical language skills: a legal English experience. Southern African Linguistics and Applied Language Studies 24(1): 23-33.

Stake RE. 1994. Case studies. In Denzin NK \& Lincoln YS (eds) Handbook of qualitative research. California: Sage, pp 236-247.

Sutton B. 1997. Writing in the disciplines, first-year composition, and the research paper. Language and Learning Across the Disciplines 2(1): 46-57.

Swales JM. 1982. The case of cases in English for academic legal purposes. International Review of Applied Linguistics 20(2): 139-148.

Swales JM. 1990. Genre analysis: English in academic and research settings. Cambridge: Cambridge University Press.

Symons M. 2002. Starting a coursework postgraduate degree: the neglected transition. Paper presented at Conference on Identity, University of Wollongong.

Toulmin SE. 1958. The uses of argument. United Kingdom: Cambridge University Press.

Tredoux C, Foster D, Allan A, Cohen A \& Wassenaar D. 2005. Psychology and Law. Lansdowne: Juta Academic.

Twining WL. 1997. Law in context: enlarging a discipline. Oxford: Clarendon Press.

Van Eemeren FH, Grootendorst R \& Kruiger T. 1987. Handbook of argumentation theory. Dordrecht: Foris.

Weber J. 2001. A concordance- and genre-informed approach to ESP essay writing. ELT Journal 15(1): 14-20.

Wisker G, Robinson G, Trafford V, Creighton E \& Warnes M. 2003. Recognising and overcoming dissonance in postgraduate student research. Studies in Higher Education 28(1): 91-105.

Yin RK. 2004. The case study anthology. London: Sage Publications. 